\title{
幼児内反膝に対する靴型装具の治療経験
}

\author{
鹿児島県立整肢園
}

西 村 謙一・肥 後勝

矢 崎 雄一郎

\section{Treatment of Infantile Bowleg Using Foot Appliances}

by

\author{
Kenichi Nishimura, Masaru Higo and Yuuichirou Yazaki \\ Kagoshima Prefectural Crippled Children's Hospital
}

\begin{abstract}
Seven cases (thirteen legs) of infantile severe bowleg were treated using foot appliances and shoe alterations with medial heightened wedge soles. Averge age of patients was 1.5 years (range, 1.3-1.8 years) at the begining of treatment. The patients used the orthosis for an average of 16 months (range, 10-23 months). Average follow-up period was 4.3 years. We used the femoro-tibial angle (FTA) and metaphyseal-diaphyseal angle (MDA) for radiographic evaluation. During the assessment no patients were found to have radiographic evidence of Blount disease. At the time of follow-up, no deformities or malalignment of the lower extremities were found and all patients obtained normal FTA and MDA. We consider this foot appliance to be useful and easy to use for patients in treating infantile severe bowlegs.
\end{abstract}

Key words : Infantile bowleg（幼児内反膝), Foot appliance（靴型装具), Blount disease（ブラント病）

\section{はじめに}

幼児内反膝は，一般に処女歩行後から 2 歳時にかけ て見られ4), 治療の必要のないものも多い。しかし， 中には変形が進行し Blount 病への進展が危惧され治 療の選択に難渋する，我々は，高度内反䐂に対し早期 から予防的に足部内側を楔状に高くした靴型装具およ び足底挿板による治療を行なってきたのでその治療経 験について報告する。

\section{対象および方法}

対象症例は, 男児 6 例, 女児 1 例の計 7 例 13 膝で あり, 治療開始時年龄は 1.3 歳加ら 1.8 歳（平均 $1.5 \pm$ 0.2 歳), 追跡調查期間は 0.8 年から 9.3 年 (平均 $4.3 \pm$ 3.0 年), 最終調查時年齢は, 2.3 歳から 11.1 歳（平均 $5.9 \pm 3.1$ 歳) である. 初診時全例内反膝, 下腿内捻,
内旋歩行があり, 内顆間距離は, $2.5 \sim 5$ 横指であっ た. 処女歩行月齢は平均 11 ケ月, 処女歩行から治療 開始までの期間は平均 7.5 ケ月であった。 Generalised joint laxityを 4 例に認めた。 X 線計測は, femolo-tibial angle (以下 FTA), 脛骨近位の metaphyseal-diaphysaeal angle (以下 MDA) を 用いた，FTA は，下肢全体のアライメントをみるが， 膝関節勒帯弛緩や荷重などの影響を受けやすい. Blount 病は, 脛骨近位での内反変形が主体であり ${ }^{3)}$, この部分の内反を表す MDA は診断, 経過をみる上 で有用であり ${ }^{3)} \mathrm{MDA} 11^{\circ}$ 以上は Blount 病への進行 が強く示唆される ${ }^{3) 4}$. 初診時, FTA は, 平均 200.7 $\pm 7.7^{\circ}\left(192^{\circ} \sim 212^{\circ}\right), \quad M D A$ は平均 $10.2 \pm 3.1^{\circ}\left(5^{\circ} \sim\right.$ $\left.15^{\circ}\right)$ であり, 内反膝を呈していたが, Blount 病に特 徵的である脛骨近位内側の骨幹端部の嘴状突出などの 所見 ${ }^{3)}$ は認めなかった. 


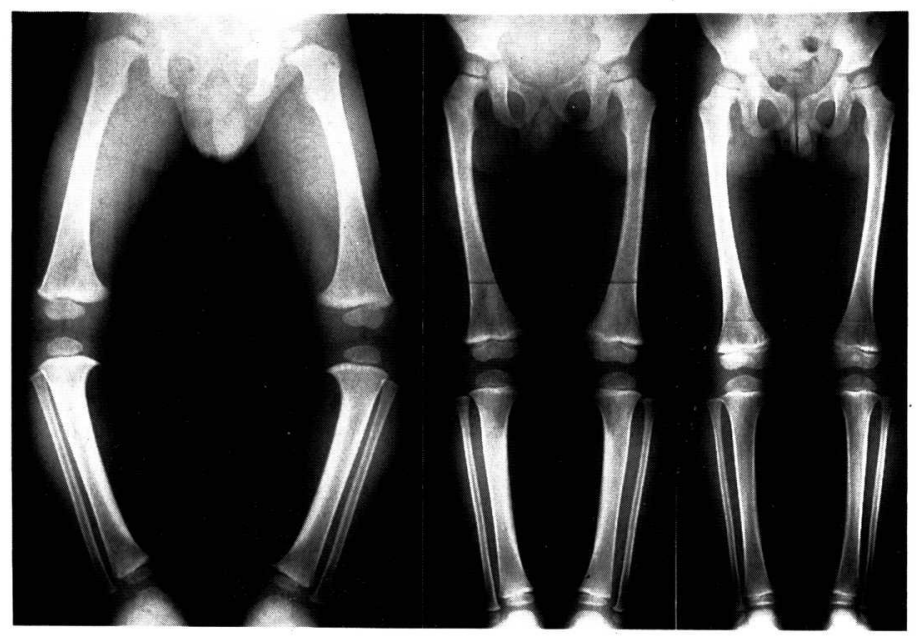

(a)

(b)

(c)

図 1 症例 男児

a) 初診時 1 歳 5 ケ月

$\begin{array}{ccc} & \text { 右 } & \text { 左 } \\ \text { FTA } & 208^{\circ} & 209^{\circ}\end{array}$

MDA $15^{\circ} \quad 15^{\circ}$

$\begin{array}{rr}\text { b) 装具終了時 } 3 & \text { 歳 } 3 \\ \text { 右 } & \text { 左 } \\ 177^{\circ} & 178^{\circ} \\ 4^{\circ} & 5^{\circ}\end{array}$

c) 最終調查時 5 歳 0 ケ月

靴型装具および足底挿板は足底内側を楔状に高くし たもので, 一般の外反足矯正用のものである ${ }^{2)}$. 適応 は, 系統疾患のない, 内顆間距離 3 横指以上の内反膝 で, FTA $195^{\circ}$ 以上, MDA 11 以上のいずれかに該当 するものとした。装具は, 内反膝が消失し, FTA $185^{\circ}$ 以下となるまで用いたが，その装着期間は平均 16.3 ケ月間であった.

\section{結果}

最終調査時, 全例外観上, 膝变形はなく, 歩容も正 常であった.

膝内反の推移を FTA の平均でみると治療開始時 $200.7 \pm 7.7^{\circ}$ が治療終了時平均 $178 \pm 3.0^{\circ}$, 最終調查時 $176 \pm 5.6^{\circ}$ と膝内反は正常範囲内に改善していた。

脛骨内反をMDA の平均でみると治療開始時 $10.2 \pm$ $3.1^{\circ}$ から治療終了時 $3.7 \pm 3.7^{\circ}$, 最終調查時も $1.8 \pm 3.6^{\circ}$ へと正常範囲内に矯正されていた.

\section{症 例 供 覧}

1 歳 5 ケ月, 男児. 初診時両側の内反膝変形を認め, $\mathrm{FTA}$ 右 $208^{\circ}$, 左 $209^{\circ}, \mathrm{MDA}$ 右 $15^{\circ}$, 左 $15^{\circ}$ であっ た. 22 ケ月間の靴型装具により内反膝は矯正され,
最終調査時まで FTA，MDA ともに正常範井であっ た（威 1 ).

\section{考察}

幼児の下肢アライメントは一般に出生時より胎内肢 位の影響で膝関節後内側部が拘縮して脛骨が大腿骨に 対して内旋しているため内反滕を呈するとされる ${ }^{1)}$. 通常は歩行開始時期より㯟関節の拘縮が自然に消失し, 2 歳頃には外反へ移行するが, 拘縮が残存し立位歩行 によって, 内反した脛骨近位内側に過剰な圧迫力が加 わり, 放置されると Blount 病へ進展する ${ }^{1)}$ とされる.

正常な下肢アライメントを獲得して脛骨近位内側の 過剰な圧迫力を除去するため一般に長下肢装具や短下 肢装具が用いられているが，亀下らは靴型装具による 幼児内反膝の治療について述べている，幼児内反膝で は勒帯機能が未熟で小児外反扁平足の様に足部が下腿 に対して外反位となり，足部の荷重点が内側に偏位し， 下肢荷重線は膝関節ではその内側を通り, 膝関節内側 に圧迫力が強く作用して内側の骨軟骨に発育障害をき たし内反㯟が増強する ${ }^{2}$ 。靴型装具は足部を内反位に 保持して足部の荷重点を外側に移動させ，荷重線を膝 外方に近づけ, 荷重線が外側に移動すれば, 膝関節の 
内側面の負荷は減少するので生理的な自然矯正を助長 し，変形の矯正をはかるものであるとしている ${ }^{2}$.

装具療法は足底装具, 短下肢装具, 長下肢装具に大 別される．長短下肢装具は，脛骨の驾曲および膝関節 のアライメントを矯正するが，足底装具に比べると， 患児の負担が大きい，これらの装具療法により脛骨近 位内側の過剩な圧迫力が除去されれば脛骨は正常に発 育するとされる。

$$
\text { ま と め }
$$

1）幼児高度内反膝に対し靴型及び足底装具の使用 により全例内反膝の矯正が得られた。

2 ）装具治療の適応は内顆間距離 3 横指以上の内反 膝で，FTA $195^{\circ}$ 以上，MDA $11^{\circ}$ 以上のいずれかに該 当するあのとした。
3 ）足底装具は, 簡便な装具で歩行時のみの使用で あるため患児への負担の少ない有用な治療法である.

\section{参考 文 献}

1）本間隆之ほか：奻児型 Blount 病の早期診断之装具療 法. 整形外科 $43: 24-32,1992$.

2）刍下喜久男 : 小児の包括医療一よくみる下肢の筋骨格 系の異常「O脚, X脚」, pp. 227-240. 東京, 診断之治 療社, 1981

3) Levine, A. M., Drennan, J. C. : Physiological Bowing and Tibia Vara. J. Bone Joint Surg., 64-A : 1158-1163, 1982.

4) Salenius, et al. : The Deveropment of the Tibiofemoral Angle in Children. J. Bone Joint surg., 57-A : 2 59-261, 1975.

5) Wilkins, K. E. : Bowlegs. Pediatr. Clin. North Am., $33: 1429-1438,1986$. 